\title{
Antimicrobial Effect of Malaysian Honey on Some Human Pathogens: an in vitro Study
}

\author{
Hassanain $\mathrm{AT}^{\mathrm{a}}$, Alyaa $\mathrm{AK}^{\mathrm{b}}$, Karim AJc \\ aDepartment of Medical Microbiology and Parasitology, School of Medical Sciences, Universiti Sains Malaysia, \\ ${ }^{b}$ Human Genome Center, School of Medical Sciences, Universiti Sains Malaysia, \\ International Medical School, Management and Sciences University
}

\begin{abstract}
Introduction: Honey has potent bactericidal activity against many pathogenic organisms, including various Gram-negative and Gram-positive bacteria. This study aimed to determine the antimicrobial effect of Malaysian honey against different species of human pathogens using optimized honey broth media. Materials and Methods: The antimicrobial activity of honey against standard strains of Gram-negative and Grampositive bacteria and yeast was tested in vitro by the broth dilution method using 10\%-100\% w/v concentrations prepared in tryptic soy broth. Results: Streptococcus pyogenes was the most sensitive pathogen, it was completely inhibited by $30 \%$ honey broth medium. The most resistant were E. faecalis, S. aureus and MRSA, but they were all completely inhibited by $80 \%$ honey broth medium. Conclusion: Honey is shown to possess antimicrobial activity against human Gram-positive and negative medically important bacteria.
\end{abstract}

\section{KEYWORDS: Antimicrobial, honey, in vitro, pathogens}

\section{INTRODUCTION}

Honey has long been considered more of a drug than nutrient. Two millennia before bacteria were identified as the cause of disease, physicians at the time were aware that certain types of honey are the best therapy particular ailments and infections. However, large variations in the in vitro antibacterial activity of various types of honey have been reported and thus hampered its acceptance in modern medicine. ${ }^{1}$ Laboratory studies and clinical trials have shown that honey is an effective broad-spectrum antimicrobial agent. Honey has been reported to have an inhibitory effect on nearly 60 species of bacteria including aerobes and anaerobes, Gram-positive and Gram-negative. Antifungal action has also been observed against the yeast Candida albicans and the most species of Aspergillus baumannii and Penicillium chrysogenum, ${ }^{2}$ as well as all the common dermatophytes. ${ }^{3}$ Malaysian honeys are well recognized because of their quality, although there are few scientific publications about their antibacterial activity. This study aimed to (i) determine the antimicrobial effect of one brand of Malaysian honey against different species of human pathogens, (ii) optimize the preparation of honey broth media used in vitro studies, and (iii) determine the dose response relationship for antibacterial activity of honey broth media.

Corresponding author:

Assoc. Prof. Dr. Karim Al-Jashamy

International Medical School,

Management and Sciences University,

Shah Alam, Malaysia

e-mail: jashamy@yahoo.com

\section{MATERIALS AND METHODS}

Honey used in this study was obtained from local commercial producers of honey (Muda Liar), and was sterilized by gamma irradiation before being used. ${ }^{4}$ Blood agar plate containing only honey was incubated overnight at $37^{\circ} \mathrm{C}$ served as a control to verify sterility. Microorganisms from the Microbiology Department in Universiti Sains Malaysia were grown on blood agar (Merck, New Jersey, USA) with/or without tryptic soy broth (Merck, New Jersey, USA). Broth dilution method was used to assess the antibacterial activity of the honey against the yeast C. albicans ATCC 10231 and 11 other bacteria, including S. aureus ATCC 25923, methicillin-resistant S. aureus (MRSA) ATCC 33591, S. bovis ATCC 33317, S. pyogenes ATCC 19615, L. monocytogenes ATCC 7644, E. faecalis ATCC 29212, A. baumannii ATCC 19606, P. aeruginosa ATCC 27853, E. coli ATCC 25922, K. pneumoniae ATCC 31488 and S. sonnei ATCC 9290. Different concentrations of honey broth media were prepared aseptically. The concentrations were given as percent \% w/v. Honey had a density of $1.40 \mathrm{~g} / \mathrm{mL}$ and $28.57 \mathrm{~mL}$ of tryptic soy broth was added to $71.43 \mathrm{~mL}$ of honey (100 g of honey) to obtain $100 \%(10 \mathrm{~g} / 100 \mathrm{ml})$ honey concentration. Serial dilutions of honey in tryptic soy broth ranging from $10-100 \mathrm{~g} / 100 \mathrm{ml}$ concentration were made and honey mixed well by vortexing before use honey in broth media. ${ }^{5}$

Cultivation of microorganisms in honey broth media The 0.5 McFarland standard $\left(1 \times 10^{8} \mathrm{CFU} / \mathrm{mL}\right)$ overnight pure culture bacterial suspensions were made in peptone water. Ten $\mu \mathrm{L}$ of each suspension $\left(1 \times 10^{6}\right.$ $\mathrm{CFU} / \mathrm{mL}$ ) was inoculated in five $\mathrm{mL}$ of different concentrations of honey broth media and incubated at 
overnight $37^{\circ} \mathrm{C}$. Then, $10 \mu \mathrm{L}$ of the growth cultures of each honey broth media was streaked evenly onto blood agar plate to obtain uniformly distributed growth. The streaked plates were incubated aerobically at $37^{\circ} \mathrm{C}$ and inspected after 24 hours. The broth cultures showing heavy growth were serially diluted with sterile broth before being incubated onto blood agar as mentioned. After incubation, the number of bacterial colonies was counted and expressed as colony forming unite (CFU) per $\mathrm{ml}$.

\section{RESULTS}

The antimicrobial effects of honey against different microorganisms are summarized in Table I, S. pyogenes is the most sensitive pathogen showing complete inhibition in $30 \%$ honey broth. The most resistant organisms were E. faecalis, S. aureus and MRSA. Some of these bacteria were completely inhibited in $80 \%$ honey broth media.

\begin{tabular}{|c|c|c|c|c|c|c|c|c|c|c|c|}
\hline \multirow[b]{2}{*}{ Microorganisms } & \multicolumn{11}{|c|}{ (CFU) mL at various concentrations of honey broth media } \\
\hline & O\% & $10 \%$ & $20 \%$ & $30 \%$ & $40 \%$ & 50\% & $60 \%$ & $70 \%$ & $\mathbf{8 0 \%}$ & $90 \%$ & $100 \%$ \\
\hline S. aureus & $3.53 \times 10^{9}$ & $1.26 \times 10^{9}$ & $1 \times 10^{8}$ & $2.6 \times 10^{6}$ & 918 & 720 & 676 & 59 & 32 & $\mathbf{0}$ & $\mathbf{0}$ \\
\hline MRSA & $1.54 \times 10^{9}$ & $1.4 \times 10^{9}$ & $1.38 \times 10^{8}$ & $8.8 \times 10^{\prime}$ & $2.78 \times 10^{4}$ & 1096 & 703 & 40 & 7 & 0 & $\mathbf{0}$ \\
\hline S. bovis & $4.4 \times 10^{5}$ & $2 \times 10^{3}$ & 116 & 39 & $\mathbf{0}$ & $\mathbf{0}$ & $\mathbf{0}$ & $\mathbf{0}$ & $\mathbf{0}$ & $\mathbf{0}$ & $\mathbf{0}$ \\
\hline S. pyogenes & $7 \times 10^{\prime}$ & $6.7 \times 10^{4}$ & 19 & 0 & o & 0 & o & o & 0 & 0 & $\mathbf{0}$ \\
\hline E. faecalis & $6.84 \times 10^{10}$ & $5.26 \times 10^{110}$ & $5.9 \times 10^{9}$ & $5.7 \times 10^{9}$ & $6 \times 10^{8}$ & $8.4 \times 10^{4}$ & $2.62 \times 10^{4}$ & $2.62 \times 10^{4}$ & 47 & $\mathbf{0}$ & 0 \\
\hline L. monocytogenes & $2.22 \times 10^{11}$ & $4.28 \times 10^{11}$ & $6.6 \times 10^{9}$ & $7.8 \times 10^{\prime}$ & 2528 & 2120 & 10 & 0 & 0 & 0 & 0 \\
\hline P. aeruginosa & $1 \times 10^{16}$ & $2 \times 10^{12}$ & $3.2 \times 10^{9}$ & $2.18 \times 10^{7}$ & 227 & o & $\mathbf{0}$ & $\mathbf{0}$ & o & $\mathbf{0}$ & $\mathbf{0}$ \\
\hline E. coli & $6 \times 10^{11}$ & $1.76 \times 10^{10}$ & $3.4 \times 10^{9}$ & $2.3 \times 10^{\circ}$ & 698 & 95 & o & o & 0 & $\mathbf{0}$ & $\mathbf{0}$ \\
\hline A. baumannii & $8.6 \times 10^{12}$ & $6.36 \times 10^{11}$ & $1.26 \times 10^{11}$ & $4.2 \times 10^{4}$ & 1400 & $\mathbf{0}$ & $\mathbf{0}$ & $\mathbf{0}$ & $\mathbf{0}$ & $\mathbf{0}$ & $\mathbf{0}$ \\
\hline K. pneumoniae & $8 \times 10^{15}$ & $1.14 \times 10^{27}$ & $5.72 \times 10^{13}$ & $1 \times 10^{16}$ & $2.4 \times 10^{\prime}$ & 49 & $\mathbf{0}$ & $\mathbf{0}$ & $\mathbf{0}$ & $\mathbf{0}$ & $\mathbf{0}$ \\
\hline S. sonnei & $1.42 \times 10^{12}$ & $6.6 \times 10^{11}$ & $6 \times 10^{11}$ & $2 \times 10^{3}$ & $2 \times 10^{4}$ & 316 & 0 & 0 & 0 & 0 & 0 \\
\hline C. albicans & $1.1 \times 10^{4}$ & 7520 & 7200 & 5600 & 2592 & 254 & 75 & $\mathbf{0}$ & $\mathbf{0}$ & $\mathbf{0}$ & $\mathbf{0}$ \\
\hline
\end{tabular}

Table I. Inhibitory of microbial growth at different concentrations of honey broth media

The percentage bactericidal activity of different concentrations of honey broth media is shown in Table II. At $10 \%$ concentration, some inhibitory effect was observed on all pathogens. C. albicans is the organisms which required the highest concentration, $70 \%$ honey broth to achieve $100 \%$ cidal effects which reveals that honey is highly active against S. bovis and P. aeruginosa where only $4 \%$ concentration was needed to achieve $50 \%$ killing. C. albicans showed the highest inhibitory concentration $\left(\mathrm{IC}_{50}\right)$ among all pathogens remaining needed to $29 \%$ concentration of honey broth to achieve $50 \%$ inhibition.

Table II. Percentage of bactericidal activity (\% killed) in different concentrations of honey broth media and the IC50 of pathogens

\begin{tabular}{|c|c|c|c|c|c|c|c|c|c|c|c|}
\hline \multirow[b]{2}{*}{ Pathogens } & \multicolumn{11}{|c|}{ Percentage of bacterial killed } \\
\hline & $\begin{array}{c}10 \% \\
\text { Honey } \\
\text { Broth }\end{array}$ & $\begin{array}{c}20 \% \\
\text { Honey } \\
\text { Broth }\end{array}$ & $\begin{array}{c}30 \% \\
\text { Honey } \\
\text { Broth }\end{array}$ & $\begin{array}{c}40 \% \\
\text { Honey } \\
\text { Broth }\end{array}$ & $\begin{array}{c}50 \% \\
\text { Honey } \\
\text { Broth }\end{array}$ & $\begin{array}{l}60 \% \\
\text { Honey } \\
\text { Broth }\end{array}$ & $\begin{array}{c}70 \% \\
\text { Honey } \\
\text { Broth }\end{array}$ & $\begin{array}{c}80 \% \\
\text { Honey } \\
\text { Broth }\end{array}$ & $\begin{array}{c}90 \% \\
\text { Honey } \\
\text { Broth }\end{array}$ & $\begin{array}{l}100 \% \\
\text { Honey } \\
\text { Broth }\end{array}$ & ${ }^{*} \mid \mathrm{C}_{50}$ \\
\hline S. aureus & 64.31 & 97.17 & 99.93 & 100 & 100 & 100 & 100 & 100 & 100 & 100 & $7 \%$ \\
\hline MRSA & 9.09 & 91.04 & 94.29 & 100 & 100 & 100 & 100 & 100 & 100 & 100 & $15 \%$ \\
\hline S. bovis & 99.55 & 99.97 & 99.99 & 100 & 100 & 100 & 100 & 100 & 100 & 100 & $4 \%$ \\
\hline S. pyogenes & 99.9 & 100 & 100 & 100 & 100 & 100 & 100 & 100 & 100 & 100 & $5 \%$ \\
\hline E. faecalis & 23.1 & 91.37 & 91.67 & 99.12 & 100 & 100 & 100 & 100 & 100 & 100 & $14 \%$ \\
\hline L. monocytogenes & 80.72 & 97.03 & 99.96 & 100 & 100 & 100 & 100 & 100 & 100 & 100 & $5 \%$ \\
\hline P. aeruginosa & 99.98 & 100 & 100 & 100 & 100 & 100 & 100 & 100 & 100 & 100 & $4 \%$ \\
\hline E. coli & 70.67 & 94.33 & 99.62 & 100 & 100 & 100 & 100 & 100 & 100 & 100 & $7 \%$ \\
\hline A. baumannii & 92.6 & 99.85 & 100 & 100 & 100 & 100 & 100 & 100 & 100 & 100 & $5 \%$ \\
\hline K. pneumoniae & 98.58 & 99.92 & 100 & 100 & 100 & 100 & 100 & 100 & 100 & 100 & $5 \%$ \\
\hline S. sonnei & 53.52 & 97.14 & 100 & 100 & 100 & 100 & 100 & 100 & 100 & 100 & $9 \%$ \\
\hline C. albicans & 31.64 & 34.55 & 54 & 76.44 & 97.69 & 99.32 & 100 & 100 & 100 & 100 & $29 \%$ \\
\hline
\end{tabular}

$* \mathrm{IC}_{50}$ is the fifty percent inhibitory concentration dose of honey for each pathogen 


\section{DISCUSSION}

The present study showed that the tested honey has some antimicrobial action from concentrations as low as $4 \%$. Significant inhibition of growth of all pathogens except C. albicans is seen at $20 \%$ concentration. This indicates that the inhibition by honey broth media probably resulted mainly from intrinsic antimicrobial properties other than its high osmolarity and acidity. The honey's antimicrobial rang effected over both Gram-positive and Gram-negative bacteria and yeast. The mode of action of honey has not yet been fully elucidated, but osmolarity, acidity, hydrogen peroxide generation and phytochemical components are all considered as contributory factors. ${ }^{6}$ Previously variations in reported antibacterial activities of difference honey varieties might be due to the amount of hydrogen peroxide and other additional antibacterial components derived from the nectar source. ${ }^{6,7}$

In undiluted honey, the osmolarity due to high sugar content and acidity undoubtedly limit bacterial growth. High viscosity of honey also plays an important role in maintaining a moist wound environment that promotes healing and provides a protective barrier against wound contamination and infection. ${ }^{8,9}$ When honey is diluted, a bee-derived enzyme (glucose oxidase) present in the honey is activated and catalyzed the slow generation of hydrogen peroxide which might inhibit the bacterial growth. ${ }^{10}$ This activity varies markedly from one type of honey to another, generally, however the phytochemical components make only a minor contribution to the antibacterial activity of honey.7 Inhibitors phenolic acids and flavonoids that are found in honey are also putative antimicrobial factors. ${ }^{11,12}$

Nzeako and Hamdi in their study of six commercial honeys found that inhibition in agar diffusion of $\mathrm{S}$. aureus, E. coli and $P$. aeruginosa did not occur at honey concentrations less than $40 \% .{ }^{13}$ They also found that C. albicans was inhibited by honey, although the zone of inhibition was small compared with other organisms. Ceyhan and Ugur ${ }^{14}$ tested 84 types of honey against eight bacteria and two fungi showed that all types of honey have broad spectrum activities. Molan6,15 suggested that only some types of honey possessed antifungal properties. However, in this study, yeast growth was less sensitive to honey as compared to bacteria, but yet it can still be completely inhibited by a higher concentration. White and his coworkers 10 suggested that bacteria are more susceptible to peroxides than molds and yeasts; other researchers have confirmed this finding. ${ }^{15,14}$ Other studies even showed no inhibitory effect of honey on the growth of C. albicans. ${ }^{8,9}$ Most published studies used diluted honey in distilled water to obtain various volume/volume $(\mathrm{v} / \mathrm{v})$ concentrations. ${ }^{2,3,16}$ By referring to the method of Al-Waili and his colleagues, ${ }^{5}$ the present work used broth for dilution, which was a suitable medium for microbial growth. Furthermore, the percentage of honey concentration was made as weight of honey in volume of tryptic soy broth; this is more acceptable since various honeys have different densities. In addition, most of the in vitro studies used honey incorporated into the agar as nutrient with brain heart infusion then inoculate the microorganism or other have used impregnated honey disc in agar diffusion test. Furthermore, previous study found that discs impregnated with various concentrations of honey added to agar plate became dry due to vaporization of fluid from the discs when incubated at $37^{\circ} \mathrm{C}$ for 24 hours. In addition, the impregnated honey may not diffuse evenly in the agar plate to show clear and obvious inhibition zone, this property makes honey a good drug to be applied at time of closing surgical wounds or wounds due to various traumas. ${ }^{17,18}$ In addition, honey also inhibits growth of nosocomial pathogens especially those not responding to the standard antibiotic therapy like MRSA. Hence, new strategies are needed in the treatment of wounds infections, along with the opportunity to use honey as a convenient, effective and less costly treatment option. Besides, there are other advantages in applying honey to the traumatized tissue around medical devices. Its anti-inflammatory effect might be expected to prevent formation of serous exudates, which can provide a good medium for growth of bacteria. Moreover, its physical properties provide moist conditions ideal for healing and it has a stimulatory action on the growth of wound repair tissues. ${ }^{19}$ Also, honey does not adversely affect human tissue ${ }^{18}$ and may even promote wound healing. ${ }^{20}$

Finally, this study has successfully proven the antimicrobial action of one brand of Malaysian honey. The properties or components within this honey may act as inhibitors that are warranted as wide spectrum antimicrobial agent for treatment of infections. Further study is needed to determine the factors that import antimicrobial properties on the Malaysian honey. These factors include the acidity, osmolarity, total sugar, flavonoids and mineral content and other biochemical properties of the Malaysian honey. In addition, further research is required not only into those honeys that possessed antibacterial properties, but also into the other health benefits of commercially produced Malaysian honey.

\section{CONCLUSION}

Malaysian honey has been shown to prevent the growth of a wide range of potential human pathogens which included 12 species of bacteria and one yeast. Thus, it has a broad-spectrum of antimicrobial activity.

\section{ACKNOWLEDGEMENT}

This study was supported by Short term grant (304/ PPSP/6131535) from Universiti Sains Malaysia. Our appreciation to the Total Health concept (THC) company / Malaysia to provide Muda Liar honey for this research. 


\section{REFERENCES}

1. Kwakman PH. Medical-grade honey kills antibiotic-resistant bacteria in vitro and eradicates skin colonization. Clin Infect Dis 2008; 46:1677-82

2. Willix DJ, Molan PC, Harfoot CG. A comparison of the sensitivity of wound-infecting species of bacteria to the antibacterial activity of manuka honey and other honey. J Appl Bacteriol 1992; 73:388-94

3. Brady NF, Molan PC, Harfoot CG. The sensitivity of dermatophytes to the antimicrobial activity of Manuka honey and other honey. Pharm Sci 1997; 2:1-3

4. Molan PC, Allen KL. The effect of gamma-irradiation on the antibacterial activity of honey. J Pharm Pharmacol 1996; 48:1206-9

5. Al-Waili NS, Akmal M, Al-Waili FS, Saloom KY, Ali. A. The antimicrobial potential of honey from United Arab Emirates on some microbial isolates. Med Sci Monit 2005; 11:433-8

6. Molan PC. The Antibacterial Activity of Honey. 1. The Nature of the Antibacterial Activity. Bee World 1992a; 73:5-28

7. Molan PC. The Antibacterial Activity of Honey. 2. Variation in the Potency of the Antibacterial Activity. Bee World 1992b; 73:59-76

8. Lusby PE, Coombes AL, Wilkinson JM. Honey: a potent agent for wound healing? J Wound Ostomy Continence Nurs 2002; 29:295-300

9. Lusby PE, Coombes AL, Wilkinson JM. Bactericidal activity of different honeys against pathogenic bacteria. Arch Med Res 2005; 36,464-7

10. White JW, Jr., Subers MH, Schepartz Al. The identification of inhibine, the antibacterial factor in honey, as hydrogen peroxide and its origin in a honey glucose-oxidase system. Biochim Biophys Acta 1963; 73:57-70

11. Weston RJ. Antibacterial phenolic components of New Zealand Manuka honey. Food Chemistry 1999; 64: 295- 301

12. Aljadi AM, Yusoff KM. Isolation and identifica -tion of phenolic acids in Malaysian honey with antibacterial properties. Turk J Med Sci 2002; 33: 229-36

13. Ceyhan N, Ugur A. Investigation of in vitro an -timicrobial activity of honey. Riv Biol 2001; 94:363-71

14. Nzeako BC, Hamdi J. Antimicrobial potential of honey on some microbial isolates. SQU Biol/Biol Forum 2000; 94: 363-72

15. Molan PC. Finding New Zealand honeys with outstanding antibacterial and antifungal activity. New Zealand Beekeeper 1997; 10: 20-6

16. Cooper RA, Halas E, Molan PC. The efficacy of honey in inhibiting strains of Pseudomonas aeruginosa from infected burns. J Burn Care Rehabil 2002; 23:366-70

17. Ndayisaba G, Bazira L, Habonimana E, Muteganya D. Clinical and bacteriological outcome of wounds treated with honey. An analysis of a series of 40 cases. Rev Chir Orthop Reparatrice Appar Mot 1993; 79:111-3

18. Molan PC. A brief review of honey as a clinical dressing. Primary Al-Jabri 1587 Intention 1998; 6: 148-58

19. Molan PC. Re-introducing honey in the management of wounds and ulcers - theory and practice. Ostomy Wound Manage 2002; 48:28-40

20. Molan PC. The role of honey in the management of wounds. J Wound Care 1999; 8:415-8 